\title{
Serum Vitamin D and Cardiometabolic Markers: A Comparative Study in Adult Men Based on Body Mass Index
}

\author{
Syed Imran Ali Shaha, Sabiha Iqbal ${ }^{\mathrm{b}}$, Mirza Zeeshan Sikandar ${ }^{\mathrm{b}}$, Umair Yaqub Qazi ${ }^{\mathrm{a}}$, Inamul Haq \\ anniversity of Hafr Al-Batin, Hafar Al Batin, Saudi Arabia \\ ${ }^{\mathrm{b}}$ Central Park Medical College, Lahore, Pakistan
}

\begin{abstract}
INTRODUCTION: Deficiency of vitamin D has been implicated in several disorders, including skeletal, immune, neural, metabolic, and cardiovascular diseases (CVDs). The impact of vitamin D deficiency on CVDs is potentially through derangement of cardiometabolic profile. The present work assessed the relationship between serum vitamin D levels and cardiometabolic markers in adult men. MATERIALS AND METHODS: A cross-sectional analytical study $(n=160)$ was conducted on adult men between the ages 35-50 years without a history of CVDs and/or diabetes, liver, or kidney disorders. Serum vitamin D, lipid profile (cholesterol, triacylglycerol; TAG, lowdensity lipoprotein; LDL, high-density lipoprotein; HDL), and renal function tests (urea, creatinine) were measured using enzyme-linked immunosorbent assays (ELISA). Pearson's correlation was used for assessing correlations between the studied parameters. Participants were further grouped as underweight, normal weight, overweight, and obese based on their BMI values, and one-way ANOVA and post-hoc Tukey's tests were done to observe group mean differences. RESULTS: Vitamin D and HDL were positively correlated $(r=0.395, p=0.000)$ while negative correlation of serum vitamin D levels was seen with TAG $(\mathrm{r}=-0.539, \mathrm{p}=0.000)$, cholesterol $(\mathrm{r}=-0.325, \mathrm{p}=0.000)$, LDL $(r=-0.541, p=0.000)$ and urea $(r=-0.514, p=0.000)$. Levels of serum vitamin $\mathrm{D}(\mathrm{p}=0.000)$ and HDL $(\mathrm{p}=0.000)$ were lower while levels of TAG $(p=0.000)$, cholesterol $(p=0.000)$, LDL $(p=0.000)$ and urea $(p=0.000)$ were higher in the overweight and obese groups. CONCLUSION: Inadequate serum vitamin D status is associated with dyslipidaemia in adult men. Moreover, obese and overweight men have lower serum vitamin D levels with pronounced dyslipidaemia, thus highlighting vitamin $\mathrm{D}$ as a potential cardiometabolic risk factor.
\end{abstract}

KEYWORDS: Cardiovascular diseases, Lipid Profile, Vitamin D, Obesity

\section{INTRODUCTION}

Vitamin D is an essential micronutrient occurring naturally in plants (ergocalciferol) and animals (cholecalciferol). It exerts a wide spectrum of biochemical and physiological actions that are pivotal to human health. Human requirement of vitamin $\mathrm{D}$ is

\section{Corresponding Author:}

Prof. Dr. Syed Imran Ali Shah

University of Hafr Al-Batin,

Hafar Al Batin,

Saudi Arabia.

Tel No: +966534510690

Email : simranali@uhb.edu.sa / s.shah10@alumni.imperial.ac.uk mainly fulfilled by the dermal conversion of 7dehydrocholesterol, an intermediate of cholesterol metabolism, into cholecalciferol in the skin by ultraviolet sun rays. Cholecalciferol is then activated by double hydroxylation in the liver and kidneys. ${ }^{1,2} \mathrm{~A}$ growing body of work has highlighted the important role of vitamin D in cardiac health. ${ }^{3}$ Inadequacy of vitamin $\mathrm{D}$ has been shown to enhance atherogenesis via activation of proinflammatory cascades. Hypovitaminosis D is linked independently to cardiovascular morbidity and mortality.4-7 Insufficient dietary intake, reduced sun exposure, old age, and/or other co-morbid conditions like obesity and diabetes are 
risk factors for vitamin $\mathrm{D}$ deficiency in individuals developing cardiovascular diseases (CVDs). ${ }^{8}$ Renal dysfunction as seen in chronic kidney disease (CKD) is also associated with both CVDs and vitamin D deficiency. ${ }^{9,10}$

Clinical parameters such as age, male gender, hypertension, obesity, and smoking are generally considered major determinants of CVDs but over the years, derangements of certain biochemical factors have also been increasingly employed for the assessment of cardiac health. High serum levels of triacylglycerol (TAG), total cholesterol and low-density lipoprotein (LDL), and low levels of high-density lipoprotein (HDL) have been associated with increased cardiovascular risk. ${ }^{11-13}$ Lifestyle factors and genetic tendencies predispose Asian populations to CVDs and the risk has been heightened by a growing trend towards obesity. ${ }^{14}$ Furthermore, Asian populations show a high prevalence of vitamin $\mathrm{D}$ deficiency. ${ }^{15}$ Association between vitamin D deficiency and obesity has also been shown and supplementation with vitamin $\mathrm{D}$ does not appear to improve vitamin D status in obese adults. ${ }^{16}$ Most of the existing data on the link between body weight, serum vitamin $\mathrm{D}$, and biochemical markers of cardiac health in the local population are inconsistent and inconclusive. The present study investigated vitamin D status and serum cardiometabolic markers including cholesterol, TAG, HDL, and LDL in adult men from the local population and sought a correlation between vitamin D and cardiometabolic markers. Serum urea and creatinine were also assessed to determine the correlation between renal function and vitamin D status in the study cohort. Further exploration of the study parameters based on body mass index (BMI) was also carried out.

\section{MATERIALS AND METHODS}

The cross-sectional study was conducted at the University of Hafr Al-Batin, Saudi Arabia. Ethical approval was granted by the institutional research committee at the University of Hafr Al-Batin and the study was completed in compliance with the Declaration of Helsinki. A total of 160 adult male subjects between the ages of 35-50 years were enrolled for the study from the local population of Lahore,
Pakistan through non-random convenience sampling after obtaining written informed consent. The sample size for this study was calculated based on the target population of 0.8 million men aged between 35 to 50 years with a $95 \%$ confidence level, $\pm 6.2 \%$ confidence interval (margin of error), and $80 \%$ power (population proportion) to ascertain significance at 5\% levels using two-tailed testing. Men with a history of CVDs and/or co-morbidities including diabetes mellitus, liver or kidney diseases were excluded. Basic demographic and anthropometric data including age, weight, and height were recorded. Calculation of body mass index (BMI) was done for each participant using the formula of body weight in kilogram (kg) divided by height in meters squared $\left(\mathrm{m}^{2}\right)$. Based on the calculated BMI values, men were segregated into four groups as underweight $\left(\mathrm{BMI}<18.5 \mathrm{~kg} / \mathrm{m}^{2}\right)$, normal weight (BMI 18.5-24.9 kg/m²), overweight (BMI $25-29.9 \mathrm{~kg} / \mathrm{m} 2$ ), and obese (BMI $\geq 30 \mathrm{~kg} / \mathrm{m} 2)$.

$10 \mathrm{ml}$ venous blood sample was collected from each subject using vacutainer tubes (Becton-Dickinson). The clinical determination of vitamin $\mathrm{D}$ levels in the serum employs 25-hydroxycholecalciferol (calcidiol), the vitamin $\mathrm{D}$ derivative having the single hepatic hydroxylation. Serum vitamin D concentrations were estimated by enzyme-linked immunosorbent assay (ELISA, Abbott Architect Chemiluminescent assay). Serum cholesterol, TAG, LDL, HDL, urea, and creatinine were measured on a digital clinical chemistry analyser (Selectra ProM Chemistry System, Elitech Group) using commercially available assay kits.

Data were recorded and analysed in an anonymous form using SPSS version 23 and normality was assessed using the Shapiro-Wilk test. Percentages were given for qualitative variables. Mean \pm SD of quantitative variables were calculated and correlations between vitamin D status and other serum markers were assessed using Pearson's correlation analysis. One-way ANOVA was applied to observe the mean differences between the groups on the whole. Post-hoc analysis was done using Tukey's test to observe individual differences between groups. A p-value of $<0.05$ was considered statistically significant. 


\section{RESULTS}

The mean age of the study participants $(n=160)$ was $38.83 \pm 4.42$ years with a range of 35 to 50 years. Participants were categorised into four groups on the basis of their BMI values (Figure 1). Mean ages in the groups were $39.25 \pm 2.30$ for Group 1 (BMI $<18.5$, $(\mathrm{n}=12), 37.66 \pm 2.84$ for Group 2 (BMI 18.5-24.9, $\mathrm{n}=67), 39.25 \pm 5.04$ for Group 3 (BMI 25-29.9, $\mathrm{n}=57$ ), and $40.88 \pm 6.20$ for Group 4 (BMI $>30, n=24$ ) with no age difference between groups.



Figure 1. Group distribution based on body mass index (BMI)

Table I shows the range and mean levels with standard deviations of vitamin $\mathrm{D}$, lipid, and renal profile markers in the entire study cohort. Mean serum vitamin D levels were in the optimal clinical range for the age group under study. Mean serum levels of the renal function markers urea and creatinine were also within the normal range. In lipid profile, mean serum TAG and LDL levels were within the acceptable range, mean serum cholesterol levels were borderline high while mean serum HDL levels slightly below the acceptable range for adult men.

Table I. Range and mean levels of serum vitamin $\mathrm{D}$ and serum markers for lipid and renal profiles in the study cohort $(n=160)$

\begin{tabular}{lll}
\hline Parameter & $\begin{array}{l}\text { Range } \\
\text { (Min - Max })\end{array}$ & Mean \pm SD \\
\hline Vitamin D (ng /ml) & $6.20-95.30$ & $45.38 \pm 25.46$ \\
$\begin{array}{l}\text { Triacylglycerol } \\
(\mathrm{TAG} ; \mathrm{mg} / \mathrm{dl})\end{array}$ & $28.00-338.00$ & $110.23 \pm 60.14$ \\
$\begin{array}{l}\text { Cholesterol } \\
\text { (mg/dl) }\end{array}$ & $134.00-482.00$ & $206.08 \pm 47.24$ \\
$\begin{array}{l}\text { High-density lipoprotein } \\
\text { (HDL; mg/dl) }\end{array}$ & $24.00-54.00$ & $39.25 \pm 7.22$ \\
$\begin{array}{l}\text { Low-density lipoprotein } \\
(\mathrm{LDL} ; \mathrm{mg} / \mathrm{dl})\end{array}$ & $77.96-223.85$ & $121.85 \pm 31.45$ \\
$\begin{array}{l}\text { Urea }(\mathrm{mg} / \mathrm{dl}) \\
\text { Creatinine }(\mathrm{mg} / \mathrm{dl})\end{array}$ & $0.350-1.207$ & $0.84 \pm 0.19$ \\
\hline
\end{tabular}

By applying Pearson's correlation, a positive correlation was observed between serum vitamin D and HDL levels $(r=0.395, p=0.000)$. Negative correlations of vitamin $D$ levels were observed with serum TAG, cholesterol, LDL, and urea (Table II, Figure 2).

Table II. Correlation of serum vitamin D with serum lipid and renal profiles

\begin{tabular}{lll}
\hline Parameter & r-value & p-value \\
\hline Triacylglycerol (TAG) & -0.539 & $0.000^{*}$ \\
Cholesterol & -0.325 & $0.000^{*}$ \\
High-density lipoprotein (HDL) & +0.395 & $0.000^{*}$ \\
Low-density lipoprotein (LDL) & -0.541 & $0.000^{*}$ \\
Urea & -0.514 & $0.000^{*}$ \\
Creatinine & -0.144 & 0.069 \\
\hline
\end{tabular}

$*$ Difference considered significant at $\mathrm{p}<0.05$.

On applying one-way ANOVA, significant differences were observed between the group means for serum 25-Hydroxyvitamin D $(p=0.000)$, TAG $(p=0.000)$, cholesterol $(p=0.000)$, HDL $(p=0.000)$, LDL $(p=0.000)$ and urea $(\mathrm{p}=0.000)$, (Table III). The post-hoc analysis further showed a significant trend of low vitamin $\mathrm{D}$ and HDL, and high cholesterol, TAG, and LDL in the overweight and obese groups as compared to underweight and normal-weight men (Tables IV \& V, Figure 2).

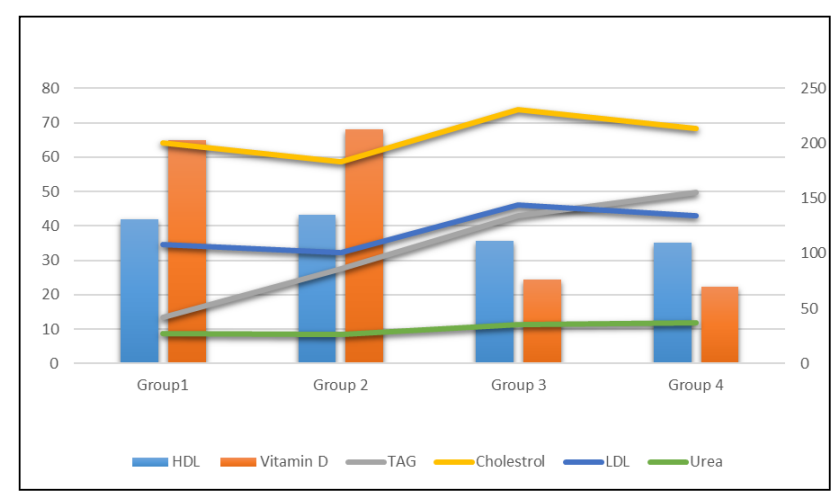

Figure 2. Correlation of serum vitamin D levels and serum lipid markers

\section{DISCUSSION}

Dyslipidaemia due to genetic or environmental influences is associated with CVDs. Obesity, a chronic anthropometric and metabolic disorder is also an established independent risk factor for CVDs and it is also associated with impaired lipid metabolism. Vitamin D deficiency has also been implicated in the atherosclerotic progression and increased risk for CVDs. 
Table III. Mean differences in serum vitamin D, lipid profile, and renal function between-groups based on body mass index

\begin{tabular}{llllll}
\hline Parameter & \multicolumn{4}{c}{ Mean \pm SD } & p-value \\
\cline { 2 - 5 } & $\begin{array}{l}\text { Group 1 (BMI } \\
<\text { 18.5) }\end{array}$ & $\begin{array}{l}\text { Group 2 } \\
\text { (BMI 18.5-24.9) }\end{array}$ & $\begin{array}{l}\text { Group 3 } \\
\text { (BMI 25-29.9) }\end{array}$ & $\begin{array}{l}\text { Group 4 } \\
\text { (BMI > 30) }\end{array}$ & \\
\hline $\begin{array}{l}\text { Vitamin D } \\
\text { (ng/dl) }\end{array}$ & $64.79 \pm 8.76$ & $68.15 \pm 11.89$ & $24.28 \pm 14.85$ & $22.22 \pm 11.56$ & $0.000^{*}$ \\
$\begin{array}{l}\text { Triacylglycerol } \\
(\mathrm{TAG} ; \mathrm{mg} / \mathrm{dl})\end{array}$ & $41.91 \pm 25.56$ & $85.65 \pm 52.32$ & $134.49 \pm 37.46$ & $155.41 \pm 75.10$ & $0.000^{*}$ \\
$\begin{array}{l}\text { Cholesterol } \\
\text { (mg/dl) }\end{array}$ & $200.44 \pm 13.80$ & $183.53 \pm 21.80$ & $230.84 \pm 63.67$ & $213.08 \pm 32.20$ & $0.000^{*}$ \\
$\begin{array}{l}\text { High-density } \\
\text { lipoprotein } \\
\text { (HDL; mg/dl) }\end{array}$ & $41.83 \pm 5.57$ & $43.29 \pm 5.74$ & $35.73 \pm 7.06$ & $35.00 \pm 5.45$ & $0.000^{*}$ \\
$\begin{array}{l}\text { Low-density } \\
\text { lipoprotein } \\
(\mathrm{LDL} ; \mathrm{mg} / \mathrm{dl})\end{array}$ & $108.19 \pm 14.03$ & $100.67 \pm 15.74$ & $144.25 \pm 34.00$ & $134.62 \pm 20.05$ & $0.000^{*}$ \\
$\begin{array}{l}\text { Urea }(\mathrm{mg} / \mathrm{dl}) \\
\text { Creatinine }\end{array}$ & $27.17 \pm 4.91$ & $26.63 \pm 4.198$ & $35.21 \pm 5.88$ & $37.02 \pm 6.40$ & $0.000^{*}$ \\
$(\mathrm{mg} / \mathrm{dl})$ & $0.747 \pm .157$ & $0.830 \pm .212$ & $0.863 \pm .150$ & $0.864 \pm .150$ & 0.244 \\
\hline
\end{tabular}

$*$ Difference considered significant at $\mathrm{p}<0.05$.

The present work determined the correlation between vitamin $\mathrm{D}$ status and the serum lipid and renal profiles in adult men and further compared the study parameters between groups based on BMI ranging from underweight to obese.

Our results have demonstrated serum HDL levels to be positively correlated with serum vitamin $\mathrm{D}$ levels. The present findings have also revealed a negative correlation between serum TAG, cholesterol, and LDL levels with serum vitamin $\mathrm{D}$ levels. These findings are consistent with the data generated in earlier studies. In a large Chinese study ( $\mathrm{n}=1475)$ by Wang et al., high TAG and

Table IV. Comparison between-group mean for serum vitamin $\mathrm{D}(\mathrm{ng} / \mathrm{ml})$

\begin{tabular}{lccc}
\hline Group I & Group J & $\begin{array}{c}\text { Mean } \\
\text { Difference } \\
(\mathbf{I}-\mathrm{J})\end{array}$ & p-value \\
\hline Group 1 & Group 2 & -3.3620 & 0.837 \\
& Group 3 & +40.5057 & $0.000^{*}$ \\
& Group 4 & +42.5708 & $0.000^{*}$ \\
Group 2 & Group 1 & +3.3620 & 0.837 \\
& Group 3 & +43.8677 & $0.000^{*}$ \\
& Group 4 & +45.9329 & $0.000^{*}$ \\
Group 3 & Group 1 & -40.5057 & $0.000^{*}$ \\
& Group 2 & -43.8677 & $0.000^{*}$ \\
& Group 4 & +2.0651 & 0.911 \\
Group 4 & Group 1 & -42.5708 & $0.000^{*}$ \\
& Group 2 & -45.9329 & $0.000^{*}$ \\
& Group 3 & -2.0651 & 0.911 \\
\hline
\end{tabular}

$*$ Difference considered significant at $\mathrm{p}<0.05$. low HDL in men and high cholesterol and high LDL in women were shown to be associated with reduced serum vitamin D. ${ }^{17}$ In another study on postmenopausal women, more than two-thirds of the subjects were shown to have vitamin $\mathrm{D}$ levels below normal and vitamin $\mathrm{D}$ deficiency was associated with low levels of HDL. ${ }^{18}$ Reduced serum vitamin D levels are associated with dyslipidaemia and the adverse effect of vitamin $\mathrm{D}$ deficiency seems to influence all serum lipid parameters. Vitamin D levels have recently been shown to negatively alter the lipid profile even in nonobese subjects, thus posing a risk for dyslipidaemia and obesity. Vitamin D deficiency in such cases has been linked with an elevation of TAG. ${ }^{19}$

The negative impact of vitamin $\mathrm{D}$ deficiency on serum lipid profile is compounded by co-morbidities like obesity, insulin resistance, and diabetes mellitus which themselves are known to cause dyslipidaemia. A crosssectional study in type 2 diabetic patients reported vitamin $\mathrm{D}$ deficiency in more than half of the study participants. Vitamin D deficient patients showed higher levels of total cholesterol, TAG, and LDL and lower HDL in comparison with those having adequate vitamin $\mathrm{D}$ status. However, a significant inverse correlation of vitamin D levels was only seen with TAG levels. ${ }^{20} \mathrm{~A}$ recent large study $(\mathrm{n}=4114)$ by Askari et al. showed vitamin $\mathrm{D}$ deficiency to be associated with reduced HDL in insulin-resistant individuals. The study further reported higher circulating levels of markers of 
Table V. Multiple comparisons between-group mean for serum lipid profile

\begin{tabular}{|c|c|c|c|c|}
\hline Parameter & Group I & Group J & Mean Difference (I-J) & p-value \\
\hline \multirow{12}{*}{$\begin{array}{l}\text { Triacylglycerol } \\
\text { (TAG; mg/dl) }\end{array}$} & \multirow[t]{3}{*}{ Group 1} & Group 2 & -43.7400 & $0.032^{*}$ \\
\hline & & Group 3 & -92.5800 & $0.000^{*}$ \\
\hline & & Group 4 & -113.500 & $0.000^{*}$ \\
\hline & \multirow[t]{3}{*}{ Group 2} & Group 1 & +43.7400 & $0.032^{*}$ \\
\hline & & Group 3 & -48.5345 & $0.000^{*}$ \\
\hline & & Group 4 & -69.7599 & $0.000^{*}$ \\
\hline & \multirow[t]{3}{*}{ Group 3} & Group 1 & +92.5745 & $0.000^{*}$ \\
\hline & & Group 2 & +48.8345 & $0.000 *$ \\
\hline & & Group 4 & -20.9254 & 0.324 \\
\hline & \multirow[t]{3}{*}{ Group 4} & Group 1 & +113.500 & $0.000^{*}$ \\
\hline & & Group 2 & +69.7599 & $0.000^{*}$ \\
\hline & & Group 3 & +20.9254 & 0.324 \\
\hline \multirow{12}{*}{ Cholesterol (mg/dl) } & \multirow{3}{*}{ Group 1} & Group 2 & -16.8793 & 0.589 \\
\hline & & Group 3 & -30.4254 & 0.116 \\
\hline & & Group 4 & -12.6667 & 0.836 \\
\hline & \multirow[t]{3}{*}{ Group 2} & Group 1 & -16.8793 & 0.589 \\
\hline & & Group 3 & -47.3047 & $0.000^{*}$ \\
\hline & & Group 4 & -29.5460 & $0.021 *$ \\
\hline & \multirow[t]{3}{*}{ Group 3} & Group 1 & +30.4254 & 0.116 \\
\hline & & Group 2 & +47.3047 & $0.000^{*}$ \\
\hline & & Group 4 & +17.7587 & 0.322 \\
\hline & \multirow[t]{3}{*}{ Group 4} & Group 1 & +12.6667 & 0.836 \\
\hline & & Group 2 & +29.54602 & $0.021 *$ \\
\hline & & Group 3 & -17.7587 & 0.322 \\
\hline \multirow{12}{*}{$\begin{array}{l}\text { High-density } \\
\text { lipoprotein } \\
\text { (HDL; mg/dl) }\end{array}$} & \multirow[t]{3}{*}{ Group 1} & Group 2 & -1.4651 & 0.875 \\
\hline & & Group 3 & +6.8333 & $0.012^{*}$ \\
\hline & & Group 4 & +6.0969 & $0.012^{*}$ \\
\hline & \multirow[t]{3}{*}{ Group 2} & Group 1 & +1.4651 & 0.875 \\
\hline & & Group 3 & +7.5616 & $0.000^{*}$ \\
\hline & & Group 4 & +8.2985 & $0.000^{*}$ \\
\hline & \multirow[t]{3}{*}{ Group 3} & Group 1 & -6.0964 & $0.012^{*}$ \\
\hline & & Group 2 & -7.5616 & $0.000^{*}$ \\
\hline & & Group 4 & +0.7368 & 0.962 \\
\hline & \multirow[t]{3}{*}{ Group 4} & Group 1 & -6.8333 & $0.012^{*}$ \\
\hline & & Group 2 & -8.2985 & 0.000 \\
\hline & & Group 3 & -0.7368 & 0.962 \\
\hline \multirow{6}{*}{$\begin{array}{l}\text { Low-density } \\
\text { lipoprotein } \\
\text { (LDL; mg/dl) }\end{array}$} & \multirow[t]{3}{*}{ Group 1} & Group 2 & +7.5203 & 0.758 \\
\hline & & Group 3 & -36.2666 & $0.000^{*}$ \\
\hline & & Group 4 & -26.4364 & $0.013 *$ \\
\hline & \multirow[t]{3}{*}{ Group 2} & Group 1 & -7.5203 & 0.758 \\
\hline & & Group 3 & -43.5870 & $0.000^{*}$ \\
\hline & & Group 4 & -33.9569 & $0.000^{*}$ \\
\hline
\end{tabular}

$*$ Difference considered significant at $\mathrm{p}<0.05$. 
inflammation and endothelial damage including interleukin-6 (IL-6), interleukin-8 (IL-8), and thrombomodulin in patients with vitamin $\mathrm{D}$ deficiency and low HDL as compared to those having normal vitamin D status and no dyslipidaemia. ${ }^{21}$ Moreover, low serum vitamin $\mathrm{D}$ in patients with non-cardiac chest pain has been associated with a reduction in HDL and an increase in HbA1c, thereby increasing the risk of cardiovascular events. ${ }^{22}$ However, supplementation with vitamin $\mathrm{D}$ has yielded mixed results. Some studies have shown vitamin $\mathrm{D}$ supplementation to improve $\mathrm{HDL}^{23}$ but a systematic review and meta-analysis conducted by Dibaba et al. showed that total cholesterol, TAG, and LDL respond favorably to supplementation but not HDL. ${ }^{24}$ These inconclusive reports leave room for further research on the use of vitamin D supplementation for impairment of lipid profile.

Our results showed serum vitamin D levels to be inversely correlated with serum urea concentration. Compromised renal function is associated with altered vitamin D signaling, potentially due to the key role played by kidneys in biochemical activation of vitamin D.9,10 The current findings also reflect higher blood urea levels in overweight and obese men but no difference in serum creatinine levels was found between groups. Nonetheless, the blood urea concentration in obese and overweight groups did not exceed the normal range for the age group under study, thus suggesting no impairment of renal function. Decreased renal function has been identified in some previous studies as a long-term complication of obesity ${ }^{25}$ but the present study lacked follow-up due to its crosssectional design.

Our findings showed vitamin D levels to be significantly lower in overweight and obese men as compared to men with normal weight. These findings are consistent with those reported in several previous studies. ${ }^{26,27}$ Vitamin D deficiency seen in obesity is suggested to be due to decreased bioavailability of vitamin $\mathrm{D}$ owing to its sequestration in adipose tissue and the effect of distributional dilution due to increased tissue mass. ${ }^{28,29}$ Our results reveal disturbances in serum lipids including an increase in TAG and LDL and a decrease in HDL in overweight and obese men. These findings are in accordance with data documented in earlier studies. ${ }^{30-32}$ Shabana et al. recently showed obese individuals to have more dyslipidaemia than healthy non-obese persons. More than half of the obese participants had aberration of all the lipid parameters studied which included cholesterol, TAG, LDL, and HDL. Hyperlipidaemia (increased cholesterol, TAG. LDL) and low HDL were more pronounced in obese patients with co-morbidities. ${ }^{33}$

In addition to the traditional cardiometabolic risk factors, inflammatory biomarkers such as $\mathrm{C}$ reactive protein and various cytokines, interleukins and adhesion molecules have recently been shown to be associated with CVDs. ${ }^{34,35}$ The present study is limited by the lack of inclusion of inflammatory biomarkers in the cardiometabolic panel owing to logistical and financial constraints. Future research work studying cardiometabolic associations of vitamin $\mathrm{D}$ with the addition of inflammatory biomarkers will help generate broader and more clinically useful data for the risk assessment of CVDs.

\section{CONCLUSION}

The present study has added important data from the local population to the evidence-based linking vitamin $\mathrm{D}$ deficiency to disturbances of body lipid metabolism and adverse cardiovascular outcomes. Obese and overweight men show derangement of lipid profile which is potentially mediated by concurrent deficiency of vitamin D. Supplementation with vitamin D, in addition to the existing guidelines for the management of obesity and its complications, may be a plausible option to minimise the cardiometabolic complications of obesity. Further research with large-scale randomised trials is warranted to establish clinical recommendations about the role of vitamin D in mitigating dyslipidaemia in an overweight and obese population.

\section{CONFLICT OF INTEREST}

None of the authors have any conflict of interest to declare. 


\section{ACKNOWLEDGEMENT}

The authors extend their appreciation to the Deanship of Scientific Research, the University of Hafr Al-Batin for funding this work through the research group project No. G-121-2020.

\section{REFERENCES}

1. Buyuker SM. Vitamin D deficiency and toxicity. Eurasian J Med Oncol 2019; 3(1):1-5.

2. Zmijewski MA. Vitamin D and human health. Int J Mol Sci 2019; 20:145.

3. Perez-Hernandez N, Aptilon-Duque G, NostrozaHernandez MC, et al. Vitamin D and its effects on cardiovascular diseases: a comprehensive review. Korean J Intern Med 2016; 31(6):1018-29.

4. Fanari Z, Hammami S, Hammami MB, Hammami S, Abdellatif A. Vitamin D deficiency plays an important role in cardiac disease and affects patient outcome: Still a myth or a fact that needs exploration? J Saudi Heart Assoc 2015; 27(4):26471.

5. Nitsa A, Toutouza M, Machairas N, et al. Vitamin D in cardiovascular disease. In Vivo 2018; 32 (5):977-81.

6. Rai V, Agrawal DK. Role of Vitamin D in Cardiovascular Diseases. Endocrinol Metab Clin North Am 2017; 46(4):1039-59.

7. Wang T, Sun H, Ge H, et al. Association between vitamin $\mathrm{D}$ and risk of cardiovascular disease in Chinese rural population. PLoS One 2019; 14 (5):e0217311.

8. Adhikari CM, Ghimire HB. Association of vitamin D and cardiovascular health. Nepalese Heart J 2018; 15(1):17-21.

9. Kaur G, Singh J, Kumar J. Vitamin D and cardiovascular disease in chronic kidney disease. Pediatr Nephrol 2019; 34(12):2509-22.

10. Gluba-Brzozka A, Franczyk B, Cialkowska-Rysz A, Olszewski R, Rysz J. Impact of vitamin D on the cardiovascular system in advanced chronic kidney disease (CKD) and dialysis patients. Nutrients 2018; 10(6):709.

11. Thomas MR, Lip GY. Novel risk markers and risk assessments for cardiovascular disease. Circ Res 2017; 120(1):133-49.
12. Ye X, Kong W, Zafar MI, Chen LL. Serum triglycerides as a risk factor for cardiovascular diseases in type 2 diabetes mellitus: a systematic review and meta-analysis of prospective studies. Cardiovasc Diabetol 2019; 18(1):48.

13. Gidding SS, Allen NB. Cholesterol and atherosclerotic cardiovascular disease: A lifelong problem. J Am Heart Assoc 2019; 8(11):e012924.

14. Volgman AS, Palaniappan LS, Aggarwal NT, et al. Atherosclerotic cardiovascular disease in South Asians in the United States: Epidemiology, risk factors, and treatments: A scientific statement from the American heart association. Circulation 2018; 138(1):e1-34.

15. Man RE, Li LJ, Cheng CY, et al. Prevalence and determinants of suboptimal vitamin D levels in a multiethnic asian population. Nutrients 2017; 9 (3):13.

16. de Oliveira LF, de Azevedo LG, da Mota Santana J, de Sales LPC, Pereira-Santos M. Obesity and overweight decreases the effect of vitamin D supplementation in adults: systematic review and meta-analysis of randomized controlled trials. Rev Endocr Metab Disord 2020; 21(1):67-76.

17. Wang Y, Si S, Liu J, et al. The associations of serum lipids with vitamin D status. PLoS One 2016; 11(10):e0165157.

18. Sarmiento-Rubiano LA, Angarita Ruidiaz JA, Suarez Davila HF, et al. Relationship between serum vitamin D levels and hdl cholesterol in postmenopausal women from Colombian Caribbean. J Nutr Metab 2018; 2018:9638317.

19. Kim MR, Jeong SJ. Relationship between vitamin $\mathrm{D}$ level and lipid profile in non-obese children. Metabolites 2019; 9(7):125.

20. Saedisomeolia A, Taheri E, Djalali M, Moghadam AM, Qorbani M. Association between serum level of vitamin $\mathrm{D}$ and lipid profiles in type 2 diabetic patients in Iran. J Diabetes Met Dis 2014; 13:7.

21. Sharif-Askari FS, Sharif-Askari NS, Halwani R, et al. Low vitamin $\mathrm{D}$ serum level is associated with HDL-C dyslipidemia and increased serum thrombomodulin levels of insulin-resistant individuals. Diabetes Metab Syndr Obes 2020; 13:1599-607.

22. Alkhatatbeh MJ, Amara NA, Abdul-Razzak KK. Association of 25-hydroxyvitamin D with HDL- 
cholesterol and other cardiovascular risk

biomarkers in subjects with non-cardiac chest pain. Lipids Health Dis 2019; 18(1):27.

23. Tavakoli F, Namakin K, Zardast M. Vitamin D supplementation and high-density lipoprotein cholesterol: A study in healthy school children. Iran J Pediatr 2016; 26(4):e3311.

24. Dibaba DT. Effect of vitamin D supplementation on serum lipid profiles: a systematic review and meta-analysis. Nutr Rev 2019; 77(12):890-902.

25. Koch VH. The effects of obesity on kidney function: a challenge for nephrologists. J Bras Nefrol 2019; 41(2):162-5.

26. Vanlint S. Vitamin D and obesity. Nutrients 2013; 5(3):949-56.

27. Soskic S, Stokic E, Isenovic ER. The relationship between vitamin $\mathrm{D}$ and obesity. Curr Med Res Opin 2014; 30(6):1197-9.

28. Wortsman J, Matsuoka LY, Chen TC, Lu Z, Holick MF. Decreased bioavailability of vitamin D in obesity. Am J Clin Nutr 2000;72:690-3 P 2000; 72:690-3

29. Vranic L, Mikolasevic I, Milic S. Vitamin D deficiency: Consequence or cause of obesity? Medicina (Kaunas) 2019; 55(9):541.

30. Rinaldi AEM, de Oliveira EP, Moreto F, et al. Dietary intake and blood lipid profile in overweight and obese schoolchildren. BMC Research Notes 2012; 5(598).

31. Feingold KR, Grunfeld C. Obesity and dyslipidemia. Feingold KR, Anawalt B, Boyce A, editors. South Dartmouth, MA: MDText.com, Inc.; 2018.

32. Milyani AA, Al-Agha AE. The effect of body mass index and gender on lipid profile in children and adolescents in Saudi Arabia. Annals African Med 2019; 18(1):42-6.

33. Shabana, Shahid SU, Sarwar S. The abnormal lipid profile in obesity and coronary heart disease (CHD) in Pakistani subjects. Lipids Health Dis 2020; 19(1):73.

34. Katsiari CG, Bogdanos DP, Sakkas LI. Inflammation and cardiovascular disease. World J Transl Med 2019; 8(1):1-8.

35. Lubrano V, Balzan S. Consolidated and emerging inflammatory markers in coronary artery disease. World J Exp Med 2015; 5(1):21-32. 